\title{
Renal scarring and vesicoureteric reflux
}

\author{
K. J. SHAH, D. G. ROBINS, * AND R. H. R. WHITE
}

From the Departments of Diagnostic Radiology and Nephrology, Children's Hospital, Birmingham

SUMMARY A review of 105 children with urinary tract infection showed an increasing prevalence of grades II-III vesicoureteric reflux with diminishing age. During infancy reflux was almost always severe, and affected boys as often as girls. Radiologically scarred kidneys were drained by refluxing ureters in $98 \%$ of cases. The prevalence of scars also rose significantly with inc reasingly severe reflux. Deterioration of existing scars or new scar formation was seen in 15 children; 18 out of 20 affected kidneys $(90 \%)$ were associated with grade III vesicoureteric reflux. 2 out of 5 children who developed new scars did so after 5 years of age.

Because severe reflux may occasionally be seen in the presence of a normal intravenous urogram, and since the finding of grades II-III vesicoureteric reflux is an indication for chemoprophylaxis, we consider cystourethrography essential in children of all ages with recurrent urinary tract infection. In children under 5 years the increased prevalence of both severe reflux and renal scarring are arguments for regarding cystourethrography as a necessary initial investigation.

Although bacteriuria and vesicoureteric reflux (VUR) are both common in childhood, their relative roles in the aetiology of renal scarring remain to be determined. Similarly the comparative value of long-term prophylactic chemotherapy and antireflux surgery in the management of VUR has not been clearly defined. As a preliminary to designing a controlled trial comparing surgery with conservative management of severe VUR, we carried out a retrospective study of children diagnosed as having urinary tract infection (UTI) and currently attending the Renal Clinic at Birmingham Children's Hospital. Our findings confirm statistically the observations of other workers (MacGregor and Freeman, 1975; Smellie et al., 1975) that there is a striking relationship between the incidence of renal scarring and the severity of VUR, and also throw further light on the reputedly rare appearance of new renal scars in patients while under observation.

\section{Patients and methods}

The case records and radiographs of all children who attended the renal clinic during 1974 with recently diagnosed or previous UTI have been reviewed. Children with neurological disorders affecting bladder function, e.g. spina bifida, were excluded, as were those with anatomical urinary tract malforma-

Received 22 July 1977

*Present address: St Luke's Hospital, Guildford, Surrey. tions, including all duplex anomalies, leaving 105 patients for the present analysis.

All patients were followed up for periods of up to 12 years, midstream urine specimens being examined microscopically at clinic attendance and cultured when indicated, as described by Robins et al. (1975). While in most cases the diagnosis of UTI was based on the finding of $\geqslant 105 / \mathrm{ml}$ pathogenic microorganisms on culture of two fresh midstream urine specimens, or growth from urine aspirated suprapubically, a small number of earlier cases had been diagnosed on less stringent criteria.

All excretory urogram (IVU) examinations were reviewed; in each case the renal length was measured and the presence of renal scars, pelvicalyceal and ureteric dilatation and striations (Astley, 1971) were noted. We defined a radiologically demonstrable renal scar as loss of parenchymal thickness associated with distortion ('clubbing') of one or more underlying calyces, with or without irregularity of the renal outline. Thus, mere distension of calyces, with preservation of acute forniceal angles and no loss of parenchymal thickness, was not considered to indicate a scar. Deterioration of an existing scar was defined as further parenchymal thinning with or without increased distortion of the underlying calyces, or extension of the scar to previously normal kidney tissue. Cystourethrogram (CUG) films were also reviewed and the severity of VUR graded as shown in Table 1. No instance of intrarenal reflux (Rolleston et al., 1974) was seen. 
Table 1 Severity grading of vesicoureteric reflux (VUR)

\begin{tabular}{ll}
\hline Grade & Radiological features \\
\hline I & $\begin{array}{l}\text { Reflux on filling or micturition, into the ureter only } \\
\text { Reflux on filling or micturition, up to the pelvicalyceal } \\
\text { II }\end{array}$ \\
III & $\begin{array}{c}\text { Reflux on fulling or micturition, up to the pelvicalyceal } \\
\text { system, and distending it }\end{array}$ \\
\hline
\end{tabular}

Table 2 Grade of VUR related to age at diagnosis, and the sex of 105 children with UTI

\begin{tabular}{|c|c|c|c|c|c|c|c|}
\hline \multirow[b]{2}{*}{$\begin{array}{l}\text { Grade } \\
\text { of } V U R\end{array}$} & \multirow[b]{2}{*}{$\begin{array}{l}\text { No. of } \\
\text { children }\end{array}$} & \multicolumn{6}{|c|}{ Age at diagnosis and sex } \\
\hline & & $\begin{array}{l}< \\
M\end{array}$ & ${ }^{r}$ & $\begin{array}{l}1-5 \\
M\end{array}$ & $F$ & $\geqslant$ & $\boldsymbol{r}$ \\
\hline $\begin{array}{l}\text { III } \\
\text { II } \\
\text { I } \\
\text { None } \\
\text { No CUG }\end{array}$ & $\begin{array}{r}32 \\
8 \\
15 \\
33 \\
17\end{array}$ & 5 & $\begin{array}{l}3 \\
1\end{array}$ & $\begin{array}{l}4 \\
1 \\
1 \\
3 \\
3\end{array}$ & $\begin{array}{l}9 \\
3 \\
7 \\
6 \\
6\end{array}$ & $\begin{array}{l}1 \\
1 \\
2 \\
2\end{array}$ & $\begin{array}{r}10 \\
2 \\
5 \\
22 \\
8\end{array}$ \\
\hline $\begin{array}{l}\text { All VUR } \\
\text { Total }\end{array}$ & $\begin{array}{r}55 \\
105\end{array}$ & $\begin{array}{l}5 \\
5\end{array}$ & $\begin{array}{l}4 \\
4\end{array}$ & $\begin{array}{r}6 \\
12\end{array}$ & $\begin{array}{l}19 \\
31\end{array}$ & $\begin{array}{l}4 \\
6\end{array}$ & $\begin{array}{l}17 \\
47\end{array}$ \\
\hline
\end{tabular}

\section{Results}

In Table 2 the incidence of VUR and its severity are related to the age when it was diagnosed and the sex of the 105 children. Each child is classified according to the maximal VUR shown in either ureter on any occasion. Although there were more than twice as many girls as boys with VUR, the female preponderance was not apparent during infancy. Moreover, the proportion of children exhibiting grades II-III VUR increased with diminishing age, the majority of infants being severely affected.

In Table 3 the incidence of scarring in 210 kidneys is related to the maximal grade of VUR shown in the ureters draining them. Since on theoretical grounds grades II-III VUR are more likely to be causally related to renal scarring than grade I VUR or none, we analysed grades II-III statistically as a single group,

Table 3 Grade of VUR related to incidence of renal scarring in 210 kidneys

\begin{tabular}{lll}
\hline & \multicolumn{2}{l}{ No. of kidneys* } \\
\cline { 2 - 3 } Grade of VUR & Total & Scarred $(\%)$ \\
\hline III & 47 & $37(79)$ \\
II & 13 & $5(38)$ \\
I & 30 & $6(20)$ \\
None: & & $0(0)$ \\
unilaterally & 20 & $1(1 \cdot 5)$ \\
No CUG & 66 & $0(0)$ \\
\hline
\end{tabular}

* Significance tests

None $v$ I $v \quad($ II + III $): \chi^{2}(v=2)=84.45 ; \mathrm{P}<0.001$

$\left(\right.$ None + I) $v($ II + III $): \chi^{2}(v=1)=77.39 ; P<0.001$

$\begin{array}{ll}\text { II } v \text { III: } & \chi^{2}(v=1)=6.06 ; P<0.025\end{array}$ and this yielded the highest $\chi^{2}$ values, though there was also a significant difference between grades II and III. Thus, although scars were seen with all grades of VUR, and in one instance where this was absent, the prevalence of scars rose significantly with increasingly severe VUR.

Details of 15 patients in whom existing scars deteriorated or new ones formed during follow-up are shown in Table 4. In Cases 7-10, who included 2

Table 4 Renal scar deterioration and new scar formation during follow-up

\begin{tabular}{|c|c|c|c|c|c|}
\hline $\begin{array}{l}\text { Case } \\
\text { no. }\end{array}$ & Sex & $\begin{array}{l}\text { Age at } \\
\text { diagnosis } \\
(y r)\end{array}$ & $\begin{array}{l}\text { Age at } \\
\text { deterioration } \\
(y r)\end{array}$ & $\begin{array}{c}\text { Grade of } \\
\text { VUR }\end{array}$ & $\begin{array}{l}\text { Recurrence of } \\
\text { bacteriuria }\end{array}$ \\
\hline \multicolumn{6}{|c|}{ Scars initially present which deteriorated } \\
\hline 1 & $\mathbf{F}$ & $7 \cdot 0$ & $9 \cdot 3$ & III & Confirmed \\
\hline 2 & $\mathbf{F}$ & $9 \cdot 0$ & $11 \cdot 2$ & III & No \\
\hline 3 & $\mathbf{F}$ & $3 \cdot 2$ & $4 \cdot 3$ & III & Confirmed \\
\hline 4 & $\mathbf{M}$ & $2 \cdot 1$ & $5 \cdot 9$ & III & No \\
\hline 5 & $\mathbf{M}$ & $7 \cdot 2$ & $10 \cdot 3$ & III & No \\
\hline 6 & $\mathbf{F}$ & $5 \cdot 1$ & $7 \cdot 5$ & I & Confirmed \\
\hline \multicolumn{6}{|c|}{ Possible scars which later became definite } \\
\hline 7 & $\mathbf{F}$ & $3 \cdot 5$ & $4 \cdot 5$ & III & No \\
\hline $8^{*}$ & $\mathbf{M}$ & $0 \cdot 1$ & $1 \cdot 9$ & III & , \\
\hline 9 & $\mathbf{F}$ & $3 \cdot 2$ & $5 \cdot 1$ & III & , \\
\hline $10^{*}$ & $\mathbf{M}$ & $0 \cdot \overline{1}$ & $1 \cdot 5$ & III & , \\
\hline \multicolumn{6}{|c|}{ New scars observed at subsequent IVU } \\
\hline 11 & $\mathbf{F}$ & $5 \cdot 4$ & $9 \cdot 2$ & II & Confirmed \\
\hline $12^{*}$ & $\mathbf{F}$ & $4 \cdot 1$ & $6 \cdot 5$ & III & No \\
\hline $13 *$ & $\mathbf{F}$ & 3.6 & $7 \cdot 8$ & III & Probable \\
\hline $14^{*}$ & $\mathbf{F}$ & $2 \cdot 6$ & $5 \cdot 9$ & III & No \\
\hline 15 & $\mathbf{F}$ & $7 \cdot 5$ & $9 \cdot 2$ & III & Confirmed \\
\hline
\end{tabular}

*Bilateral scarring and VUR.

nfants with 'gassy' abdomens at the time of IVU examination, we could not be certain whether scars were present initially, and these are shown as a separate group. In all 15 patients this deterioration had occurred by the time of the next IVU, and in $\mathbf{1 8}$ out of the 20 affected kidneys $(90 \%)$ the draining ureter exhibited grade III VUR. UTI had been diagnosed in all the children at the time of presentation but, since most were subsequently maintained on chemoprophylaxis, only 5 had further episodes of confirmed bacteriuria before the radiologically observed deterioration.

\section{Case reports}

The case histories of 5 children (Cases 11-15, Table 4) in whom scars developed in eight previously unscarred kidneys are given, since this phenomenon is reputedly a rare occurrence (Blank, 1973; Smellie and Normand, 1975).

Case 11. A girl aged 5 years presented with left loin pain and fever. Diagnosis of UTI was confirmed and initial IVU (Fig. 1) was normal. 6 months later a 
CUG showed grade II VUR on the left side. Clinic attendance was irregular and she had four recurrences of UTI during the next 3 years. Repeat IVU at age 9 showed marked parenchymal thinning at the left upper pole and clubbing of the underlying calyces (Fig. 2), while CUG showed persistent grade II VUR on the left side. The right side remained normal throughout.

Case 12. A 4-year-old girl was found to have UTI when investigated for 2 years' history of anorexia and lethargy. IVU showed normal appearances, but her
CUG showed bilateral grade III VUR. After initia treatment she received continuous chemotherapy, without demonstrable recurrence of UTI. 2 years later focal scarring with associated calyceal dilatation was seen at both upper poles. Although 7 years later there had been no further scarring, renal growth remained poor and bilateral grade III VUR persisted.

Case 13. A 7-year-old girl was referred in chronic renal failure and found to have shrunken kidneys. CUG (Fig. 3) showed bilateral grade III VUR, with

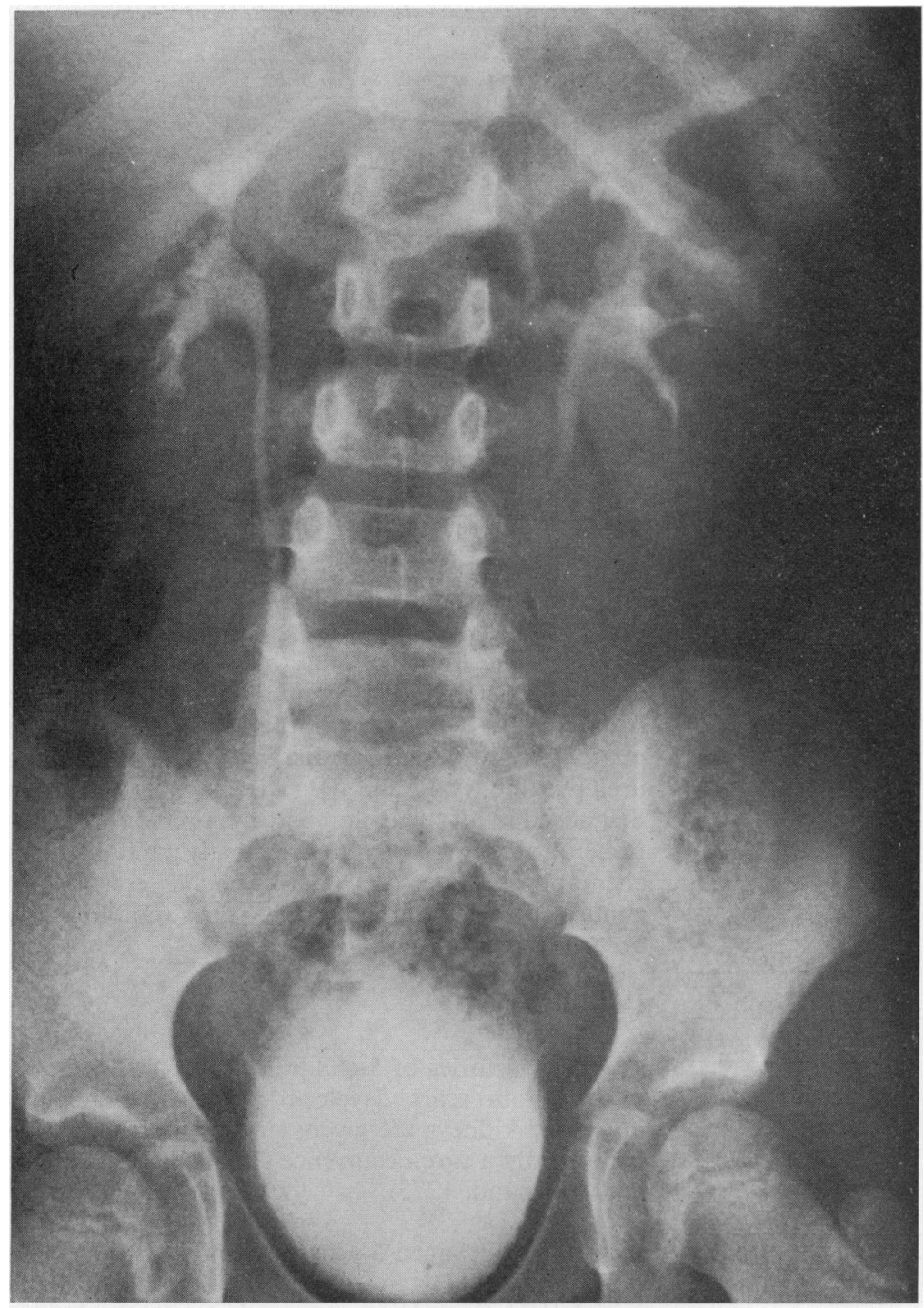

Fig. 1 Case 11. IVU, 197I. (a) Full-length, (b) crosskidneys, (c) tracing of (b). Regular renal outlines, without scarring. Note the splenic impression on the left kidney, The pelvicalyceal systems are normal and the ureters undilated. 


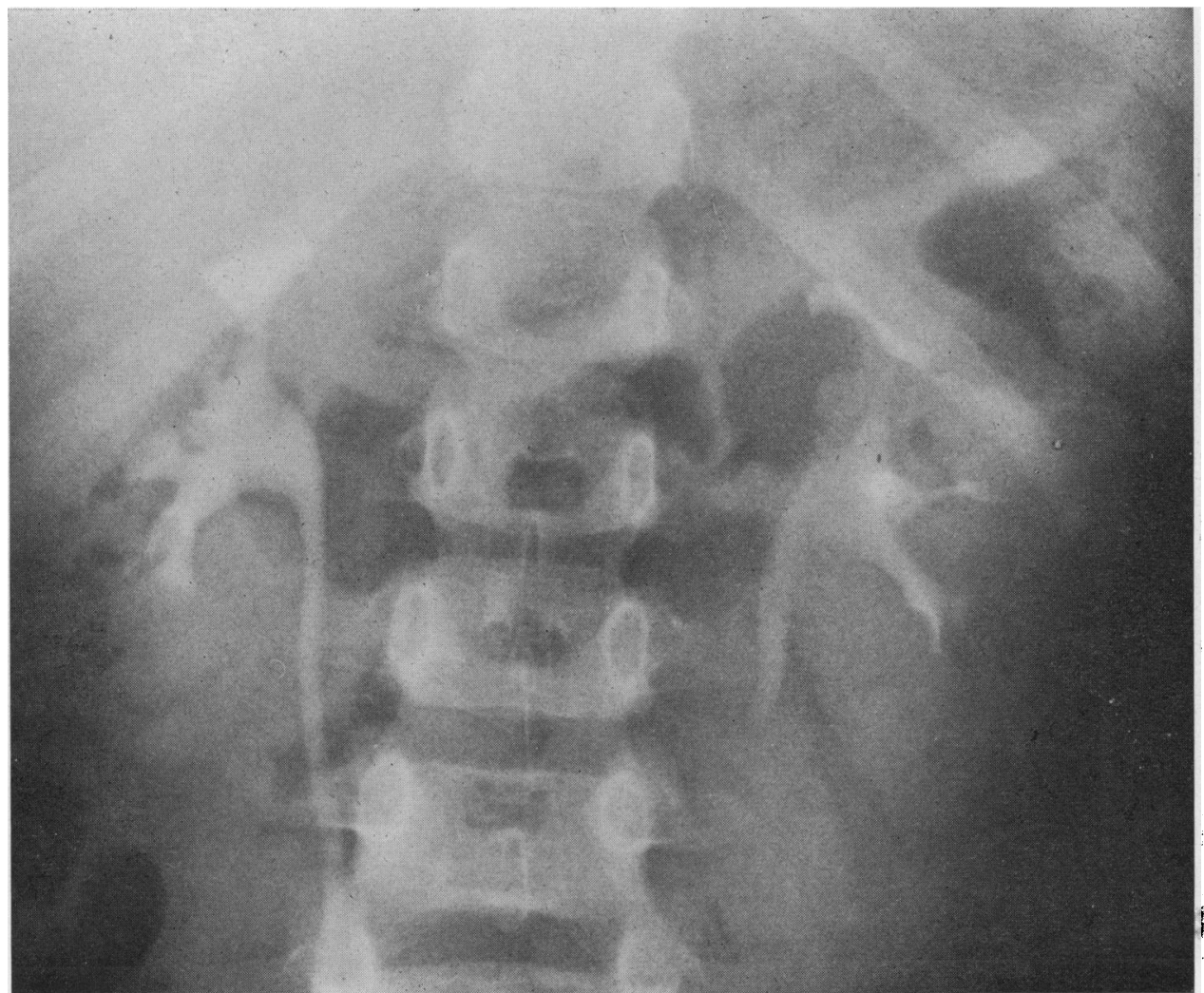

(b)
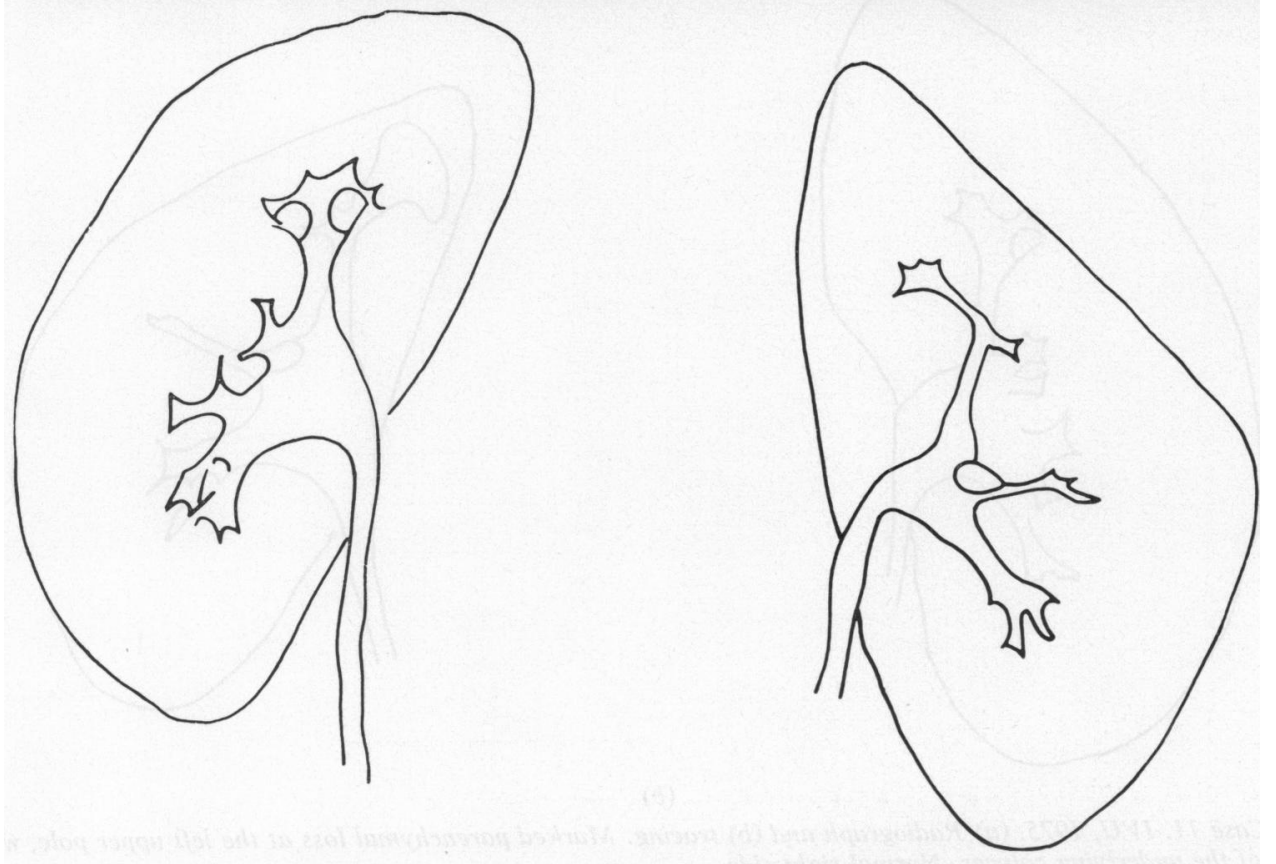

(c) 


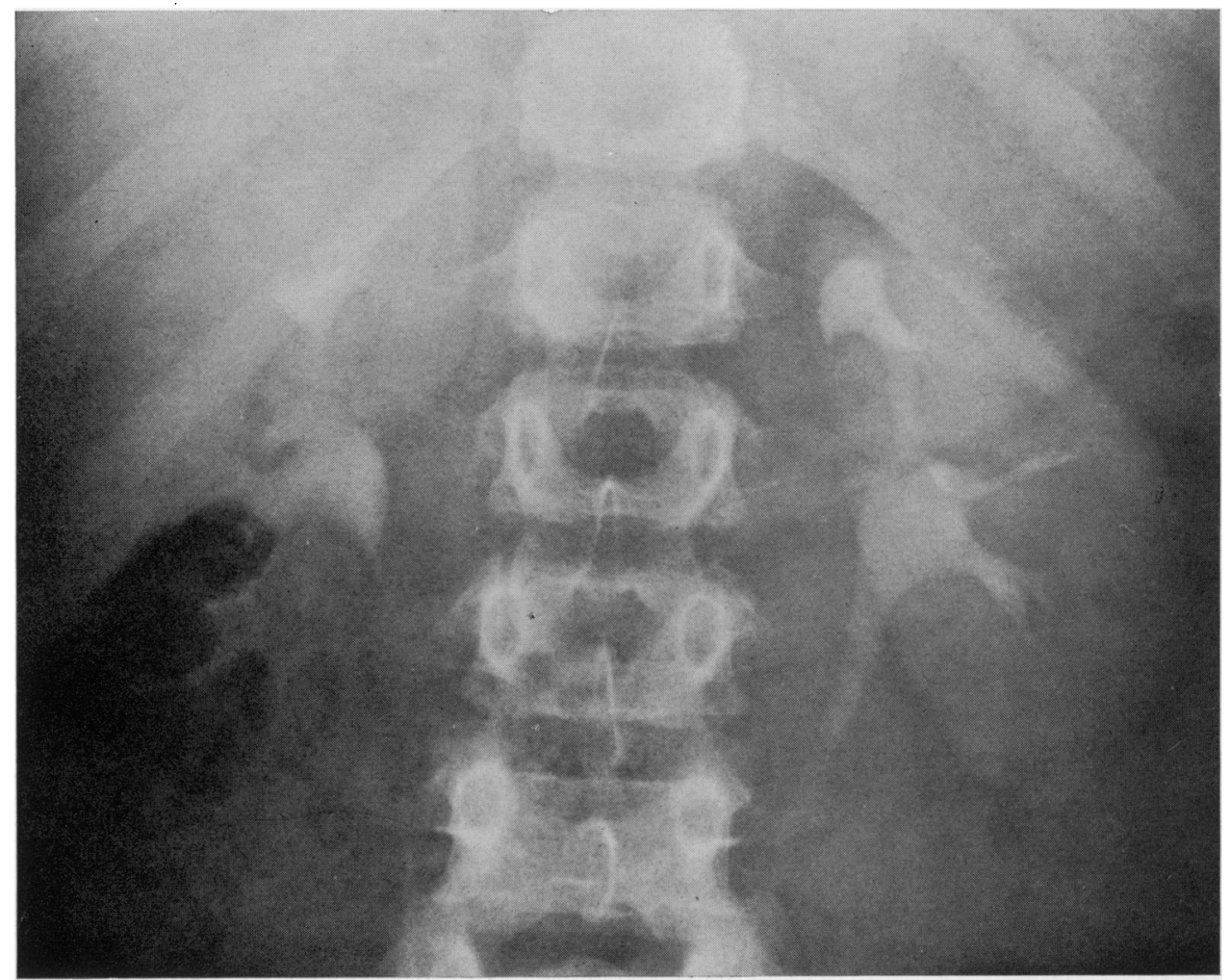

(a)
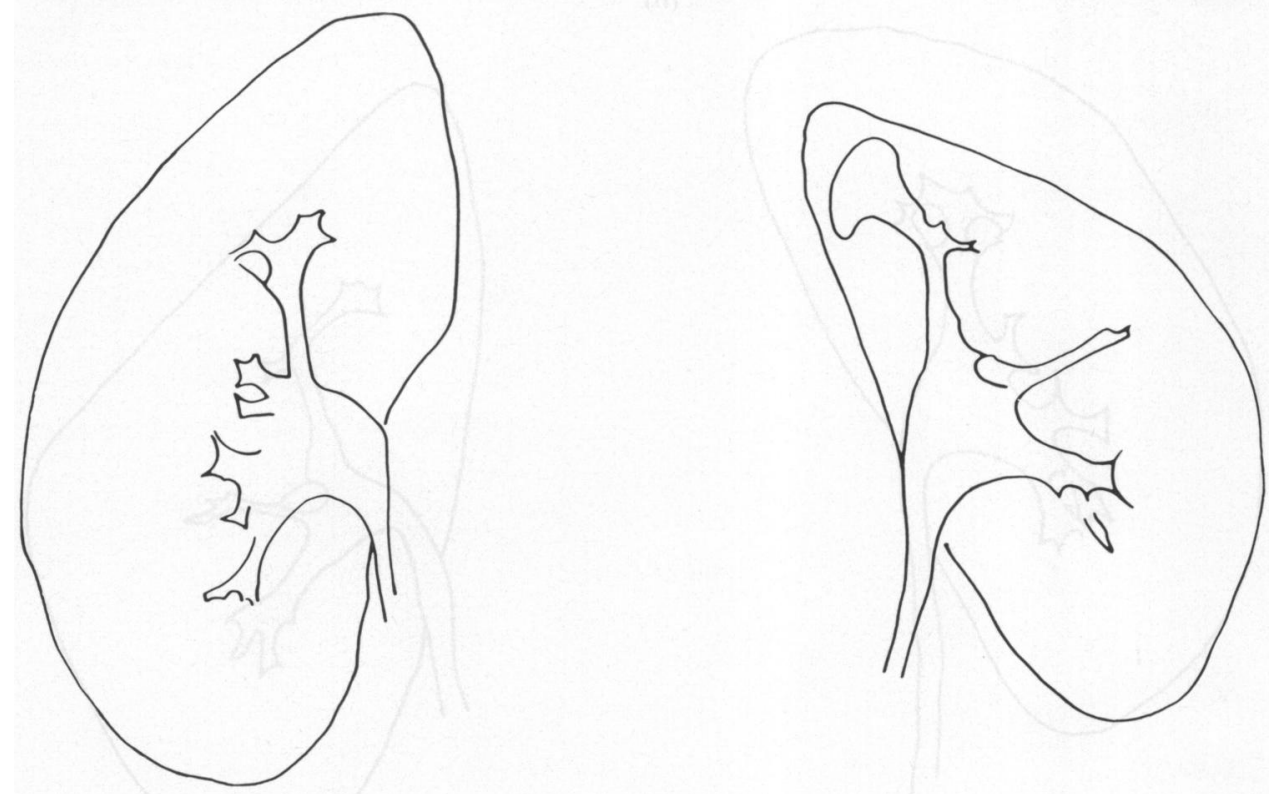

(b)

Fig. 2 Case 11. IVU, 1975. (a) Radiograph and (b) tracing. Marked parenchymal loss at the left upper pole, with clubbing of the underlying calyces. Normal right side. 


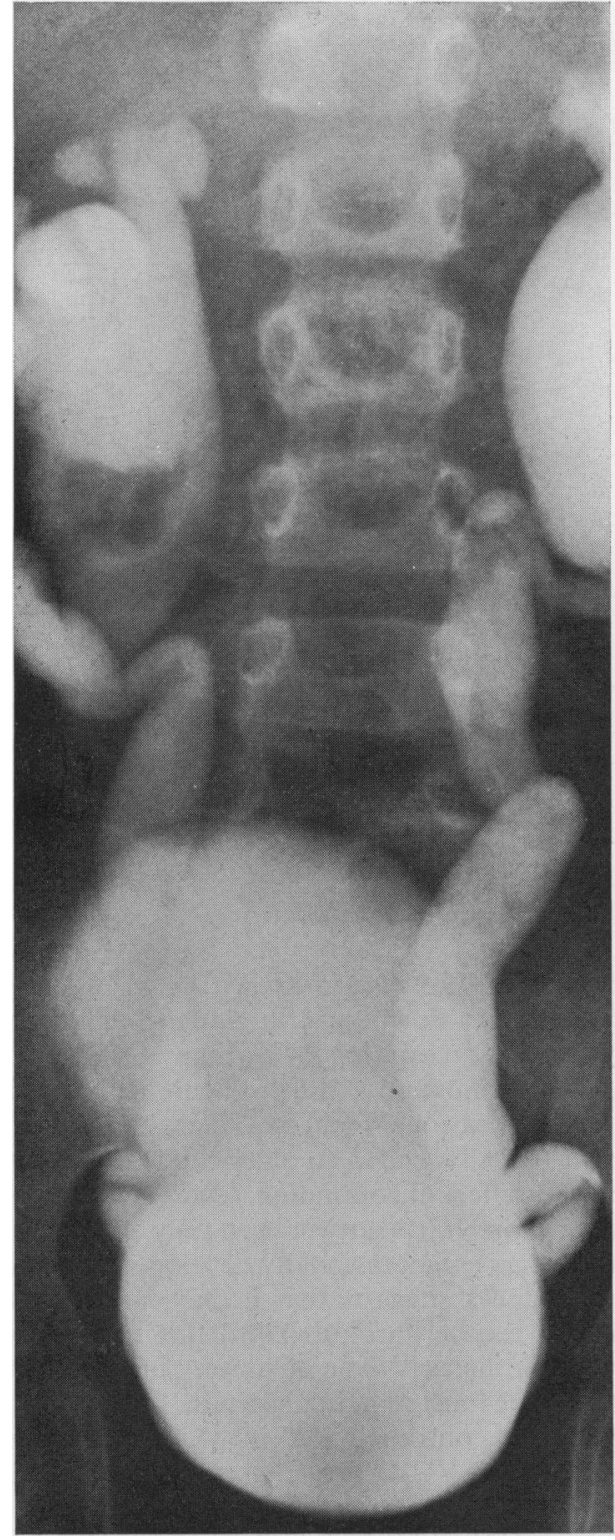

Fig. 3 Case 13. CUG, 1974. Bilateral grade III VUR on filling, shown here, and increasing on micturition. Although the ureters are grossly dilated and tortuous and the bladder of large capacity, the latter emptied completely on voiding.

grossly dilated, tortuous ureters, suggesting that the reflux was longstanding. Normal ureteric peristalsis was observed on screening. Despite the large capacity of the bladder, it emptied completely and there was no evidence of neurological or obstructive lesions.
4 years previously an IVU carried out because of recurrent UTI was reported normal; review of the films showed no abnormality (Fig. 4). At that time CUG was not performed. Renal function continued to deteriorate and she received a cadaveric transplant 2 years later.

Case 14. Investigations for failure to thrive showed UTI in a 2-year-old girl. IVU showed slight generalised calyceal dilatation without scarring, and the CUG bilateral grade III VUR. Infection did not recur, but the next IVU, just before her sixth birthday, showed scarring at both upper poles, with marked calyceal clubbing and pelvic striation. 2 years later there was no further deterioration but bilateral grade III VUR had persisted and there was no renal growth.

Case 15. A 7-year-old girl was referred with a history of recurrent UTI treated by her general practitioner. Initial radiological examinations showed minimal dilatation of one of the right lower group of calyces without loss of renal parenchyma, and bilateral grade III VUR. Bacteriuria recurred 5 months later, but for the next 6 years she received continuous chemotherapy with no recurrence. Increased calyceal dilatation and lower pole scarring was present on the IVU carried out 20 months later. Subsequent radiological examinations showed no further scarring and satisfactory renal growth, while the VUR, although still bilateral, diminished in severity to grade $\mathbf{I}$.

\section{Discussion}

Our findings agree with the well-established relationship between bacteriuria, reflux, and renal scarring (Smellie et al., 1964, 1975). The correlation between VUR and scarring in our series is highly significant; $98 \%$ of damaged kidneys were drained by refluxing ureters. As others have reported (MacGregor and Freeman, 1975; McLachlan et al., 1975; Smellie et al., 1975), the prevalence of scarring rises with increasingly severe reflux. Moreover, $90 \%$ of kidneys in which new scars developed or existing ones deteriorated were associated with grade III VUR. Bailey (1973) introduced the term 'reflux nephropathy' for this association between VUR and renal scarring, removing the emphasis from infection as the primary cause of the scarring.

Although all the children whom we studied originally had infection and many experienced recurrences, it is noteworthy that only one-third of those showing scar formation or deterioration had demonstrable reinfection during the observation period. While this might be construed as indicating that VUR can cause renal damage in the absence of 


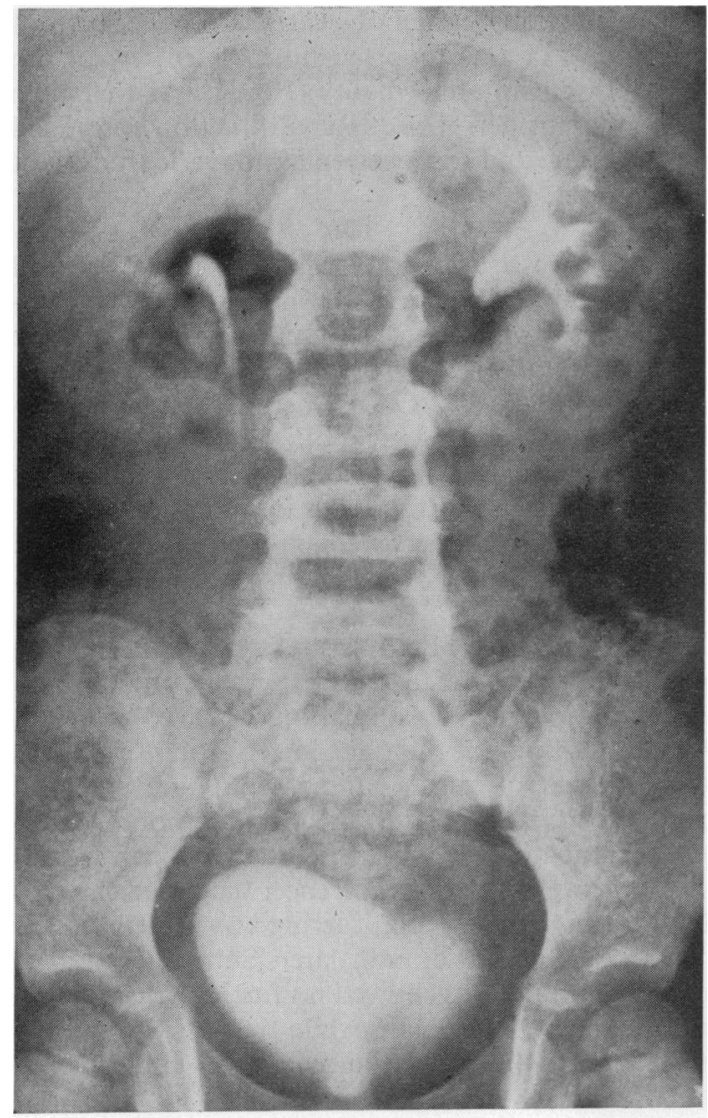

(a)

bacteriuria, it must be appreciated that the radiologically apparent scar is a late manifestation of renal injury, and the finding of normal kidneys on IVU does not eliminate the possibility that the scarring process has already been initiated (Scott, 1975) as a result of previous infection associated with reflux. Although sterile reflux has been shown experimentally to cause renal damage in pigs (Hodson et al., 1975), the mechanism was one of partial urethral obstruction, whereas in the children we have studied there was free bladder drainage. Moreover, in considerable experience of urological radiology in children without UTI (e.g. for recurrent haematuria, percutaneous renal biopsy, etc.), we have not seen the appearances characteristic of "chronic atrophic pyelonephritis' (Hodson and Wilson, 1965). We therefore favour the view that infection plays a part in the aetiology of human renal scarring.

In assessing the value of surgical reimplantation of the ureter, the natural history of VUR must be taken into account. MacGregor and Freeman (1975)

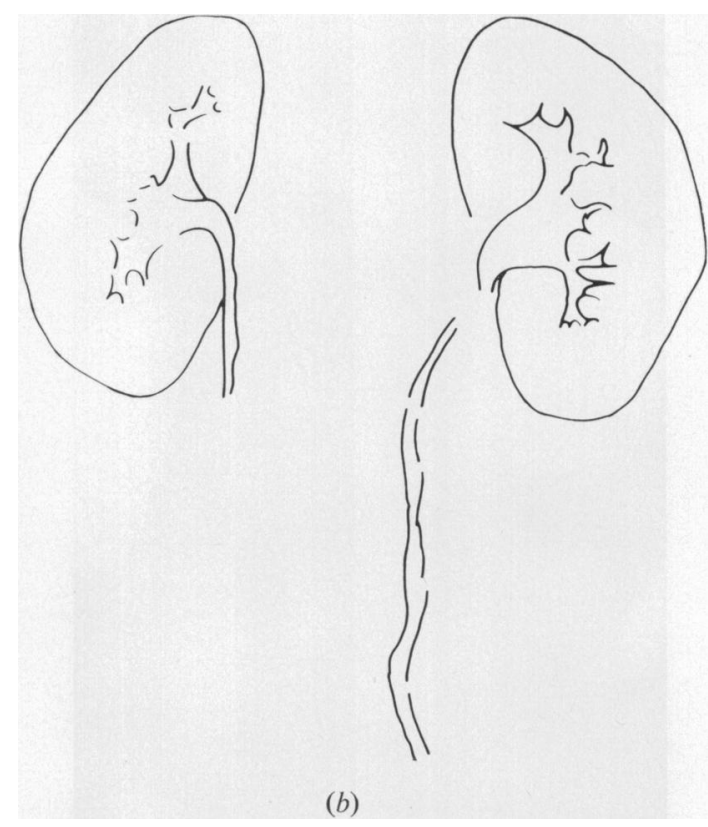

Fig. 4 Case 13. IVU, 1970. (a) Radiograph and (b) tracing. Normal appearances, including undilated ureters.

reported complete disappearance in $44 \%$ and improvement in a further $14 \%$, while Smellie et al. (1975) reported cessation in as many as $\mathbf{8 0} \%$ after prolonged follow-up. This phenomenon might explain the occasional renal scarring with minimal or no reflux, usually seen in an older child-for example Case 6. The effect of continuing, severe reflux on such damaged kidneys has not yet been fully assessed. The fact that scars can occasionally develop in previously normal kidneys suggests that it may, under certain circumstances, be harmful. Until this is more fully understood, the exact role of surgery in the management of VUR must remain uncertain, but we are now conducting a controlled trial in which age-matched children with VUR are randomly allocated to surgical or conservative management.

Much recent published evidence has emphasised the greater vulnerability of the kidneys to the effects of severe VUR during infancy (Rolleston et al., 1970, 1975) and early childhood (Rolleston et al., 1974; MacGregor and Freeman, 1975; Smellie et al., 1975), and our findings support this. Community screening programmes have been directed mainly at schoolgirls (Savage et al., 1973; Asscher et al., 1973; Edwards et al., 1975), and only small numbers of preschool children have been investigated (Davies et al., 1974; Boothman et al., 1974; Kunin et al., 1976). The study of Boothman et al. (1974) suggests that bacteriuria is 
by no means rare in boys under 5 years, in contrast to older boys (Kunin et al., 1962; Meadow et al., 1969). Moreover, our findings, like those of MacGregor and Freeman (1975) and Smellie et al. (1975), show at least as many infant boys as girls with reflux severe enough to be potentially damaging. Future screening programmes should focus attention on preschool children of both sexes.

It is also apparent that fresh scars may rarely develop after the age of 5 years, as illustrated by Cases 11 and 14 and as reported by Filly et al. (1974), Hugosson et al. (1976), and Smellie et al. (1975). Furthermore, we have on several occasions observed normal urographic appearances in the presence of grades II-III VUR (Figs 1-4), as did McLachlan et al. (1975). These findings have led us to question the management advocated by Bailey (1973) and by MacGregor and Freeman (1975), who argued that CUG was not indicated in a child over 5 years of age with UTI and normal kidneys on IVU. In our present state of knowledge, the finding of grades II-III VUR must indicate continuous chemoprophylaxis coupled with prolonged follow-up to protect the renal parenchyma from the potential risk of bacterial invasion. Despite its unpleasantness, we therefore consider CUG essential, even when the IVU is normal, in children of all ages with recurrent infections. In the case of children under 5, our finding of a higher prevalence of severe reflux, together with the acknowledged vulnerability of young kidneys to its effects, is a strong argument for regarding CUG in this age group as a necessary initial investigation.

We are indebted to Dr R Astley and Mr J. J. Corkery for encouragement; to Professor E. G. Knox for help with statistical analysis; to the Medical Illustration Department for the figures; and Miss R. Mason and Miss V. A. Bailey for secretarial assistance.

\section{References}

Asscher, A. W., McLachlan, M. S. F., Verrier Jones, R., Meller, S., Sussman, M., Harrison, S., Johnston, H. H., Sleight, G., and Fletcher, E. W. (1973). Screening for asymptomatic urinary-tract infection in schoolgirls. Lancet, 2, $1-4$.

Astley, R. (1971). Urinary tract striations in children: some experimental observations. British Journal of Radiology, 44, 452-456.

Bailey, R. R. (1973). The relationship of vesico-ureteric reflux to urinary tract infection and chronic pyelonephritis -reflux nephropathy. Clinical Nephrology, 1, 132-141.

Blank, E. (1973). Calicectasis and renal scars in children. Journal of Urology, 110, 255-258.

Boothman, R., Laidlaw, M., and Richards, I. D. G. (1974). Prevalence of urinary tract infection in children of preschool age. Archives of Disease in Childhood, 49, 917-922.

Davies, J. M., Gibson, G. L., Littlewood, J. M., and Meadow, S. R. (1974). Prevalence of bacteriuria in infants and preschool children. Lancet, 2, 7-10.
Edwards, B., White, R. H. R., Maxted, H., Deverill, I., and White, P. A. (1975). Screening methods for covert bacteriuria in schoolgirls. British Medical Journal, 2, 463-467.

Filly, R., Friedland, G. W., Govan, D. E., and Fair, W. R. (1974). Development and progression of clubbing and scarring in children with recurrent urinary tract infections. Radiology, 113, 145-153.

Hodson, C. J., and Wilson, S. (1965). Natural history of chronic pyelonephritic scarring. British Medical Journal, 2, 191-194.

Hodson, C. J., Maling, T. M. J., McManamon, P. J., and Lewis, M. G. (1975). The pathogenesis of reflux nephropathy (chronic atrophic pyelonephritis). British Journal of Radiology, Suppl. 13.

Hugosson, C. O., Chrispin, A. R., and Wolverson, M. K. (1976). The advent of the pyelonephritic scar. Annales de Radiologie, 19, 1-6.

Kunin, C. M., Zacha, E., and Paquin, A. J., Jr. (1962). Urinary-tract infections in schoolchildren. I. Prevalence of bacteriuria and associated urological findings. New England Journal of Medicine, 266, 1287-1296.

Kunin, C. M., DeGroot, J. E., Uehling, D., and Ramgopal, V. (1976). Detection of urinary tract infections in 3- to 5 -year-old girls by mothers using a nitrite indicator strip. Pediatrics, 57, 829-835.

MacGregor, M. E., and Freeman, P. (1975). Childhood urinary infection associated with vesico-ureteric reflux. Quarterly Journal of Medicine, 44, 481-489.

McLachlan, M. S. F., Meller, S. T., Verrier Jones, E. R., Asscher, A. W., Fletcher, E. W. L., Mayon-White, R. T., Ledingham, J. G. G:, Smith, J. C., and Johnston, H. H. (1975). Urinary tract in schoolgirls with covert bacteriuria. Archives of Disease in Childhood, 50, 253-258.

Meadow, S. R., White, R. H. R., and Johnston, N. M. (1969). Prevalence of symptomless urinary tract disease in Birmingham schoolchildren. I. Pyuria and bacteriuria. British Medical Journal, 3, 81-84.

Robins, D. G., White, R. H. R., Rogers, K. B., and Osman, M. S. (1975). Urine microscopy as an aid to detection of bacteriuria. Lancet, 1, 476-478.

Rolleston, G. L., Shannon, F. T., and Utley, W. L. F. (1970). Relationship of infantile vesicoureteric reflux to renal damage. British Medical Journal, 1, 460-463.

Rolleston, G. L., Maling, T. M. J., and Hodson, C. J. (1974). Intrarenal reflux and the scarred kidney. Archives of Disease in Childhood, 49, 531-539.

Rolleston, G. L., Shannon, F. T., and Utley, W. L. F. (1975). Follow-up of vesico-ureteric reflux in the newborn. Kidney International, 8, S-59-S-64.

Savage, D. C. L., Wilson, M. I., McHardy, M., Dewar, D. A. E., and Fee, W. M. (1973). Covert bacteriuria of childhood: a clinical and epidemiological study. Archives of Disease in Childhood, 48, 8-20.

Scott, J. E. S. (1975). The role of surgery in the management of vesico-ureteric reflux. Kidney International, 8, S-73-S-80.

Smellie, J. M., and Normand, I. C. S. (1975). Bacteriuria, reflux, and renal scarring. Archives of Disease in Childhood, 50, 581-585.

Smellie, J. M., Hodson, C. J., Edwards, D., and Normand, I. C. S. (1964). Clinical and radiological features of urinary infection in childhood. British Medical Journal, 2, 12221226.

Smellie, J., Edwards, D., Hunter, N., Normand, I. C. S., and Prescod, N. (1975). Vesico-ureteric reflux and renal scarring. Kidney International, 8, S-65-S-72.

Correspondence to Dr K. J. Shah, Department of Diagnostic Radiology, Children's Hospital, Ladywood Middleway, Birmingham B16 8ET. 